\title{
Política, agricultura e a reconversão do capital do tráfico transatlântico de escravos para as finanças brasileiras na década de $1850^{1}$
}

\author{
Artur Vitorino $^{2}$
}

\begin{abstract}
Resumo
O artigo enfoca como, após 1850, com a cessação do tráfico transatlântico de africanos escravos, o capital, antes engatado nesse negócio, passou a irrigar o meio circulante (a moeda e o crédito), reforçando, assim, a economia de mercado já existente na Corte Imperial, mas, a partir de então, com força para configurar nesta cidade uma economia urbana de profundas conseqüências para os agricultores escravistas do Vale do Paraíba ligados ao comércio exterior, e dependentes do crédito e da moeda ali alocados. O assentamento urbano do capital dos mercadores negreiros foi deliberado pelo Partido Conservador.
\end{abstract}

Palavras-chave: Capital financeiro; Economia nacional; Tráfico de escravos; Brasil - Século XIX; Agricultura.

\section{Abstract \\ Politics, agriculture and the reconversion of the transatlantic slave trade capital to Brazilian finances in 1850'}

The article emphasizes how, after 1850, with the cessation of the transatlantic African slave trade, the capital, rather linked in this business, passed to irrigate the finance capital (the coin and the credit), reinforcing, then, the trade economy also extant in the Imperial Court but, hereafter, stronger enough to build in this city a urban economy with profoundest consequences to the farms of the Vale do Paraíba who used slaves, were linked in the foreign trade, and were dependent of the credit and of the coin allocated there. The urban settlement of the black slave trade capital was deliberate by the Conservative Party.

Key words: Finance capital; National economy; Black slave trade; Brazil - Century XIX; Agriculture.

JEL N26, R11.

\section{Introdução}

O capital e o lucro envolvidos no tráfico negreiro mostraram-se determinantes para transformar a cidade do Rio de Janeiro em um centro financeiro, comercial e consumidor. No início da década de 1850, com o fim do comércio de "carnes humanas" no Atlântico Sul, a reciclagem do capital dos

(1) Trabalho recebido em junho de 2007 e aprovado em dezembro de 2007.

(2) Professor da Pontíficia Universidade Católica de Campinas (PUC Campinas), SP, Brasil. E-mail: arturvitorino@uol.com.br.

Economia e Sociedade, Campinas, v. 17, n. 3 (34), p. 463-491, dez. 2008. 
mercadores negreiros foi observada nos seguintes setores de reconversão na praça comercial do Rio, com as ocorrências: do aumento das importações na capital do Império e a transferência de moedas de ouro para o mercado brasileiro; dos investimentos nas sociedades anônimas fundadas no Rio a partir de 1850 - bancos, casas comerciais e empresas - que vão hipertrofiar especulativamente o mercado de ações e produzir o "encilhamento" de 1857 e a crise comercial de 1864; do financiamento creditício para o tráfico inter-regional de escravos do Norte para o Sul do Império; e da injeção de capitais em empresas que cartelizaram o mercado urbano alimentício.

Especialmente depois de 1850, com a quebra da autarquia fazendeira, ordinariamente a zona cafeicultora recorreu ao capital financeiro instalado na Corte. Com isso, a fazenda produtiva é alimentada pela economia urbana que, por sua vez, absorve os rendimentos monetizados da agricultura exportadora. Presa ao entroncamento que convergiu o veio exportador ao importador, a economia urbana e mercantil da cidade do Rio de Janeiro apresentou um dinamismo elitista, pois o seu processo de crescimento foi incapaz de incorporar o conjunto de sua população aos frutos da modernização desencadeada pela revolução industrial, mas conseguiu produzir uma reposição permanente de renda para os detentores do meio circulante (moeda e crédito).

No texto que segue, foram analisados os reflexos financeiros que o fim do tráfico negreiro imprimiu na economia mercantil e cafeeira nacional que, a partir de então, se centralizou na capital do Império brasileiro, a cidade do Rio de Janeiro. Tal ação centralizadora foi dirigida pelo Partido Conservador após a reforma financeira realizada pelo gabinete chefiado por Itaboraí. ${ }^{3}$

\section{$1 \mathrm{O}$ assentamento urbano do capital negreiro e a agricultura}

Para Luiz Felipe de Alencastro, por ser o tráfico transatlântico de africanos escravos de fundamental importância para a formação econômica, social e territorial do Brasil, ${ }^{4}$ a sua função dentro do colonialismo português foi duplamente articulada: o monopólio português se exercia no comércio de mercadorias entre o Brasil e a Europa, mas também no comércio de escravos entre

(3) Joaquim José Rodrigues Torres, depois visconde de Itaboraí, chefiou o 11ํㅡㄹ gabinete que durou de 11 de maio de 1852 a 6 de setembro de 1853, e acumulou, como era de regra no período, a presidência do Conselho e a pasta da Fazenda. Foi o fundador do terceiro Banco do Brasil a se instalar aqui, que, por suas agências e filiais, podia servir a todas as províncias, sendo concedido a esse banco o privilégio de emissão. Com isso, o banco adquiriu o caráter de regulador da circulação, e com ele contratou a substituição dos bilhetes do Tesouro por notas bancárias conversíveis.

(4) Cf. Alencastro (2000). 
o Brasil e as zonas africanas de tráfico, sobretudo de Angola, de onde vieram 70\% dos escravos importados no século XVIII. ${ }^{5}$ Nessa perspectiva, o processo de ruptura com a metrópole foi o resultado de uma dupla dissociação: de um lado, há absorção do comércio de mercadoria pela Inglaterra; do outro, a autonomização do tráfico negreiro, que, a partir do último quartel do século XVIII, é progressivamente controlado pelos negociantes luso-brasileiros do Rio de Janeiro e da Bahia (Alencastro, 1987, p. 131-147). Dessa forma, o tempo da economia brasileira é marcado por dois ponteiros: o primeiro aponta para a Europa; o segundo, para a África (Alencastro, 1980).

A partir de 1808, com a abertura dos portos, a Inglaterra, sendo a grande beneficiária dessa abertura, passa a controlar dois terços das trocas atlânticas efetuadas pelo mercado brasileiro; o terço restante desse mercado continua nas mãos dos negociantes luso-brasileiros até 1850. Desse modo, somente depois de 1850 a economia brasileira se transforma em economia periférica do centro industrializado (Alencastro, 1985-1986, p. 525-526). Cessado o tráfico, afirma Alencastro (1997, p. 37),

ocorre um retorno das divisas obtidas nas vendas de produtos de exportação e até então reservadas para financiar a compra de africanos. O efeito na balança comercial e na balança de pagamentos do Império é imediato. Comparando-se o qüinquiênio de 1845-50 ao de 1850-5 (...), constata-se que o valor das importações do Rio de Janeiro cresce uma vez e meia. Vários fatores demonstram que houve um forte acréscimo na entrada de importados - bens de consumo semiduráveis, duráveis, supérfluos, jóias etc. - destinados aos consumidores endinheirados da corte e das zonas rurais vizinhas.

Nesse sentido, quando comparados os valores das importações na alfândega do Rio de Janeiro entre os dois qüinqüênios - o $1^{1^{\circ}}$, de 1845 a 1850, apresentando o valor total de $140,307: 998 \$ 310 ;^{6}$ e o $2^{\underline{o}}$, de 1850 a 1855 , com o valor total de 237,076:914\$636 - avantaja-se o $2^{\circ}$ qüinqüênio em relação ao $1^{\circ} \mathrm{em}$ 96,768:916\$326, num acréscimo de 68,9\%, dando assim um aumento médio de $13,78 \%$ por ano. Esse notável incremento no consumo de produtos importados teve a sua maior elevação no ano 1851-1852, quando alcançou o valor de $56,681: 926 \$ 170$, representando um aumento de 101,1\% em relação às médias

(5) O Rio de Janeiro, rivalizando com a Bahia, constituía-se a principal entrada de africanos escravizados para serem "consumidos" no Brasil a partir do último quartel do século XVIII. Entre 1795 e 1811, o valor das importações de escravos foi considerável, representando cerca de um terço das importações do Rio de Janeiro.

(6) Até 1942, a moeda brasileira foi o mil-réis, grafada 1\$000. Mil mil-réis, por sua vez, eram chamados de conto ou conto de réis e grafados 1:000\$000.

Economia e Sociedade, Campinas, v. 17, n. 3 (34), p. 463-491, dez. 2008. 
anuais anteriores, sendo a maior do decênio 1845-1855, e de toda a história da alfândega do Rio de Janeiro até o ano de $1855^{7}$

Ao examinar os valores dos principais artigos de importação entre os anos de 1850-1851 e 1851-1852 registrados pela alfândega do Rio de Janeiro, poucos foram os produtos importados que tiveram o seu volume diminuído de um ano para o outro, tendo a maioria deles nesse intervalo sofrido um aumento acima de $100 \%$ no valor importado. No intervalo de apenas um ano, é notória a diferença entre a importação de bens de capital (as máquinas), de bens intermediários (ferro e cobre em bruto) e de combustível industrial (carvão mineral) e a importação de bens manufaturados (o maior valor representado pela manufatura de algodão), bens de consumo duráveis, semiduráveis e não duráveis, supérfluos, moedas de ouro e prata, obras de ouro e prata e jóias. Inativos muitos capitais após a cessação do tráfico de africanos escravos, uma parte da vultosa soma de capital negreiro foi reconvertida para a Corte através do ouro entesourado, ${ }^{8}$ do comércio e do crédito.

Dizia-se, na época, "que as despezas particulares excessivas e a substituição gradual de antigos fazendeiros, trabalhadores e economicos por seus filhos e sucessores, que não reunem iguaes predicados", tinham contribuído muito para o excessivo consumo de mercadorias estrangeiras, como anotou o conselheiro Souza Franco. ${ }^{9}$ Uma febre consumista toma conta do mundo urbano brasileiro mais intensivamente toma conta da Corte Imperial. Com o capital proveniente do extinto tráfico negreiro, alimentação, perfume, piano, remédio, máquina, roupa, relógio, louça, artigo de cerâmica, sela e equipamento para equitação, sombrinha, palheta, capa de chuva, charuto, arma de fogo, tinta para escrever, cofre de ferro, caixão mortuário, pó para limpar prataria, bicicleta, tesoura, relógio, jóias, moedas

(7) Luiz Antonio de Sampaio Vianna, "Relatorio do inspetor da Alfandega do Rio de Janeiro", Jornal do Commercio, Rio de Janeiro, 10 set. 1855, p. 1-2. Segundo contabilizava Bernardo de Souza Franco, no exercício de 1851 a 1852, o valor das importações em todo o Império correspondeu a 91.442:191\$000. Desse modo, só a alfândega do Rio de Janeiro representava o percentual de 37,2\% de todo o valor movimentado pelas alfândegas nacionais nesse ano. Cf. Souza Franco, "A crise monetaria", Correio Mercantil. Rio de Janeiro, 24 maio 1853, p. 1.

(8) Ao procurar adequar o mercado brasileiro às normas de troca no mercado internacional, a Reforma Monetária de 1846 adota os princípios do padrão-ouro, fixando o câmbio a 27 pence por mil-réis, e estabelecendo a $2 \$ 500$ a oitava de ouro de 22 quilates. No entanto, após sete anos dessa reforma, que causou uma desvalorização da moeda mil-réis, um observador escrevia ("A questão bancaria”, Correio Mercantil. Rio de Janeiro, 25 maio 1853, p. 1-2.) "que nossas moedas de ouro cunhadas segundo esse padrão [da Reforma de 1846] ainda não forão exportadas ou fundidas, e que a oitava desse metal importado das nações cultas vem trocar-se aqui pelo valor de $4 \$ 000$ nem mais nem menos". (Os grifos são do original). Se, de um lado, essa desvalorização não arrefeceu as importações, de outro, ela incentivou a reconversão do ouro negreiro em moeda nacional. Em 1864, o Relatório da Fazenda estimou em 16.000:000\$000 o capital reconvertido do tráfico. Cf. Granziera (1979, p. 42, nota 71).

(9) Souza Franco, “A situação economica e financeira do Brazil. II.”, Bibliotheca Brasileira. Revista mensal por uma associação de homens de letras. Tomo I - $\mathrm{n}^{\circ}$ 2. Rio de Janeiro, Typ. Perseverança, 1863, p. 114. Neste texto, optamos por manter a ortografia original em todas as transcrições, nos nomes próprios e títulos de jornais. 
de ouro e prata, etc., importados chegam aos montes para o público consumidor brasileiro. ${ }^{10} \mathrm{O}$ consumo de supérfluos era tão grande, que um articulista do Correio Mercantil sugeria que cada casa que tivesse um piano deveria pagar um imposto bem alto. ${ }^{11,12}$

E como o comércio no porto do Rio foi grande, com a importação feita em escala gigantesca, os negociantes de fazenda de grosso trato (o alto comércio atacadista) estabeleceram um "convênio" com as casas importadoras. Aqueles, sob multa de 4:000\$000, foram obrigados a comprar somente das casas importadoras que se comprometiam a vender seus produtos somente naquela cidade. Ao fim desse "convênio" seria, então, de prevenir que os compradores do interior fossem diretamente abastecidos pelos importadores.

Mesmo com o mercado abarrotado de mercadorias importadas, essa prática monopolizadora não permitiu que tal excesso pudesse produzir uma diminuição nos preços das mercadorias, atingindo no ano de 1852 um desconto de somente $1 \%$ em relação ao ano anterior.

Essas modificações ocorridas no comércio foram impulsionadas pelas divisas antes retidas no tráfico de africanos. No entanto, a lei Eusébio de Queiroz, de 4 de setembro de 1850, não conseguiu reverter imediatamente para outros segmentos da economia os capitais até então envolvidos no negócio de escravos instalados na costa d'África e no Brasil. Além das medidas legislativas contra o tráfico, o governo brasileiro precisou desmantelar esse negócio, mandando, em 1851, destruir e confiscar os bens de negociantes portugueses envolvidos com o tráfico de africanos, deportando-os. Subjugado, desorganizado e cessado o tráfico - por uma lei que não falha - os capitais antes envolvidos nesse comércio procuraram outros canais e lançaram-se ao novo campo. O espírito de empresa apareceu com toda a força e a superabundância desses capitais sem emprego:

creou opportunidades que não forão perdidas para muitos melhoramentos locaes [na Corte Imperial], tendo por base facilitar rapidas communicações com o interior. Formarão-se varias companhias com privilegio de governo que darão emprego a um capital já subscripto de 13 mil contos ou um milhão e 500 mil libras. Entre estas está a da continuação do caminho de ferro de Petropolis até a Parahyba; duas linhas de caminhos de ferro em Minas Geraes, a navegação do Mucury e a do Amazonas.

(10) A capitalização apresentada a partir de 1850 configurou um sistema de crédito que, em grande medida, foi criado pela posição e força financeira das casas importadoras. As casas comerciais, geralmente ligadas à venda por atacado de produtos importados, financiavam a venda de seus produtos sob a forma de crédito ao fornecedor. Após a crise de 1857, esse sistema de crédito era criticado pelos comerciantes intermediários que vendiam mercadorias importadas a varejo pelo interior do país.

(11) Conforme os cálculos de Bernardo de Souza Franco, "um individuo que ganhe 1:000\$000 por anno gasta pelo menos 50 por cento desta somma em generos importados que pagão 30 por cento de impostos". "A crise monetaria", Correio Mercantil. Rio de Janeiro, 24 maio 1853, p. 1.

(12) "Carnaval", Jornal do Commercio. Rio de Janeiro, 10 mar. 1859, p. 1.

Economia e Sociedade, Campinas, v. 17, n. 3 (34), p. 463-491, dez. 2008. 
(...) Formárão-se tambem dous bancos de hypothecas, como meios addicionaes de achar emprego para os capitaes superabundantes ...

(...) Fizerão-se grandes operações em cambio; as apolices augmentaárão de valor; as transacções monetarias forão limitadas durante os ultimos mezes [do ano de 1852]; a mania por acções ainda existe parcialmente, porém emquanto a moeda abundar ficarão ellas com toda a probabilidade a preços acima de seu absoluto valor. ${ }^{13}$

Como indicaram as pesquisas de Eulália Maria Lahmeyer Lôbo, o comércio interprovincial e a deportação de portugueses também não foram capazes de absorver todo o capital envolvido no negócio de escravos, pois:

Se uma parte dos mercadores de escravos alocou recursos diretamente na produção, servindo historicamente como um dos caminhos de transição ao capitalismo, guardando um caráter especulativo de ganhos vultosos e a curto prazo, não é menos certo que o mercado financeiro arrebanhou grande parte desses recursos, sendo capaz de permitir a captação por produtores diretos que começavam a organizar a produção em bases capitalistas (Lôbo, 1978, p. 211.)

Sendo assim, para Lahmeyer Lôbo não é eventual a coincidência entre a abolição do tráfico, a multiplicação do crédito e o primeiro surto manufatureiro. No entanto, se parte do capital negreiro foi convertido para a produção manufatureira, ele só o foi indiretamente e em pequenas somas. O próprio Irineu Evangelista de Souza, quando lidera um grupo de empresários para “(...) reunir os capitais, que se viam repentinamente deslocados do ilícito comércio, e fazê-los convergir a um centro onde pudessem ir alimentar as forças produtivas do país", ${ }^{14}$ na prática o seu faro empresarial foi dirigido a constituir um banco comercial privado, fundando o Banco do Brasil, o segundo que com este título aqui se instalou. ${ }^{15} \mathrm{E}$ nessa conjuntura de incorporação de bancos, como decorrência do capital ocioso pela cessação do tráfico negreiro e do grande surto cafeeiro, o crescimento manufatureiro ocorrido no Rio de Janeiro era derivado como afirmam Maria Bárbara Levy e Ana Maria Ribeiro de Andrade - "de uma maior diversificação dos investimentos favorecidos pela organização da Bolsa de Valores, que centralizava ativo mercado de debêntures e ações. "16

(13) "Retrospecto annual de 1852", Rio Mercantile Journal. Rio de Janeiro, 10 jan. 1853. Transcrito em Correio Mercantil. Rio de Janeiro, 14 jan. 1853, p. 2-3.

(14) Irineu Evangelista de Souza. Visconde de Mauá. Autobiografia, exposição aos credores e ao público, seguida de $O$ meio circulante no Brasil. Rio de Janeiro, Zélio Valverde, 1948, p. 126.

(15) O primeiro banco do Brasil foi criado em 1808, começou as suas operações em 1809 e liquidou-se em 1829.

(16) Levy e Andrade (1985, p. 26). Para as autoras, em 1860, "já é possível perceber (...) um significativo elemento de mudança, quando constatamos que o Banco Mauá Mac Gregor financiava a empresa Luz Stearica (Moinho da Luz), mas operações como esta são isoladas, e insuficientes para descaracterizar a ênfase comercial do capital bancário." No entanto, convém lembrar que, no período de 1854/1864, o então diretor-presidente da Luz Steárica era o Barão de Mauá, também acionista majoritário do Banco Mauá Mac Gregor. 
No início da década de 1850, as transações comerciais do Império tomaram um maior desenvolvimento, não só com referência aos negócios exteriores, como aos do interior, constituindo-se a praça comercial do Rio de Janeiro a principal praça comercial do Império. ${ }^{17}$ Em razão disso, Mauá projetou e levou a efeito a criação de um banco na capital do Império, o qual obteve estatutos por decreto n. 801 de 2 de julho de 1851, com o capital de 10.000:000\$000, dividido em 20.000 ações.

Instalado a partir de setembro de 1851, o Banco do Brasil começou a funcionar com o capital efetivo de 2.000:000\$000, o qual no ano seguinte subiu a 4.999:100\$000, e em 1853 à soma de 8.000:000\$000, conforme pode ser observado no movimento do banco de 1851 a 1853 no quadro abaixo:

\begin{tabular}{l|c|c|c|c}
\hline Anos bancários & Capital realizado & $\begin{array}{c}\text { Emissão de } \\
\text { vales }\end{array}$ & $\begin{array}{c}\text { Resumo das } \\
\text { Operações }\end{array}$ & Dividendos \\
\hline 1851 (set. a dez.) & $2.000: 000 \$$ & $93: 000 \$$ & $12.201: 000 \$$ & \\
\hline 1852 & $4.999: 100 \$$ & $1.594: 000 \$$ & $18.744: 000 \$$ & 8,33 \\
\hline 1853 & $8.000: 000 \$$ & $1.937: 600 \$$ & $21.633: 000 \$$ & 8,55 \\
\hline Média & - & $1.765: 800 \$$ & $17.537: 000 \$$ & 8,44 \\
\hline
\end{tabular}

Fonte: Sebastião Ferreira Soares, Elementos de Estatistica. Tomo I. Rio de Janeiro, Typographia Nacional, 1865, p. 171.

$\mathrm{Na}$ época da organização desse banco, havia superabundância de dinheiro, pois até meados do ano de 1850, a importação de escravos africanos no Brasil empregava uma parte importante do capital flutuante do país. Com a repressão do tráfico e liquidação pronta dessas transações, o capital antes empregado no tráfico, repentinamente deslocado, procurou emprego no mercado de descontos enquanto não descobria aplicação mais vantajosa. Assim, era evidente que a repentina diminuição das transações volumosas a que dava lugar o suprimento de trabalho à sociedade brasileira tornou desnecessária a mesma soma de meio circulante que previamente existia; o que explica a sua abundância nesse período.

Ao mesmo tempo, a enorme colheita de café - o principal produto de exportação do país - de 1850 a 1851 deveria aumentar de novo o volume das transações e encarecer o valor do meio circulante; porém foi tão grande essa colheita e tão vantajoso o preço do gênero nos mercados de consumo, que desde logo a elevação do câmbio permitiu o ingresso de metais que subiu nesse ano, conforme os melhores dados da época, a 12.000:000\$ (doze mil contos de réis). Esses metais foram prontamente amoedados, aumentando assim a massa do meio circulante nessa proporção. "Foi em taes circumstancias" - esclarecia o conselho

(17) Soares (1865, Tomo II, p. 15-42). 
de direção do Banco do Brasil aos seus acionistas - "que se estabeleceu este Banco." 18

Mas não foi somente o Banco do Brasil que absorveu a superabundância de dinheiro que circulava na praça comercial do Rio de Janeiro. O banco comercial do Rio de Janeiro também teve o seu capital dobrado a partir de 1851 . Esse banco começou a funcionar em janeiro de 1839 com o fundo de 388:700\$, o qual em dezembro desse mesmo ano se achava elevado a 2.073:000\$. Depois da aprovação dos seus estatutos por decreto de 23 de junho de 1842, no fim desse mesmo ano achava-se novamente elevado o seu capital realizado a 2.500:000\$, que, no início de 1851, alcançou a cifra de 5.000:000\$.

Ao tomar a direção de regular as operações do estabelecimento, o segundo Banco do Brasil tomava dinheiro a prêmio de $4 \%$ e o empregava a prêmio de $6 \%$. Posteriormente, devido à enorme acumulação de capitais que regurgitavam em seus cofres, esse Banco do Brasil, em combinação com o Banco Comercial, diminuiu em $1 \%$ a taxa de descontos e dos juros.

Esse dinheiro barato induziu, como é natural, o aparecimento de algumas empresas, bem como a organização das instituições de crédito. Sendo em sua maior parte organizadas sem um plano ou estudo metódicos, as empresas e sociedades anônimas fundadas nesse período tinham por fim principal o jogo da agiotagem de suas ações. ${ }^{19}$

A partir de 1853, principiou-se a formular projetos de sociedades anônimas sobre crédito, e outras sobre melhoramentos materiais e industriais. Mas assim que esses projetos se achavam organizados e assinadas as listas dos subscritores, eram imediatamente lançadas as cautelas das ações à venda na praça do comércio. A febre da agiotagem assaltou o país pela primeira vez também em 1853, quando se começou a distribuir as ações de um outro Banco do Brasil, agora o terceiro, que teve, de fato, o seu funcionamento iniciado somente em 10 de abril de $1854 .^{20}$

(18) "Banco do Brasil", Correio Mercantil. Rio de Janeiro, 13 jul. 1853, p. 2. Compunham o conselho de direção do Banco do Brasil os seguintes Srs.: Irenêo Evangelista de Souza; José Antonio de Figueiredo Junior; Militão Maximo de Souza; José Bernardino Teixeira; João Ignacio Tavares; Manoel Joaquim Ferreira Netto; Antonio Ribeiro Queiroga.

(19) Cf. Crônica de José de Alencar escrita no Correio Mercantil de 21 de janeiro de 1855. Como também, do mesmo autor, "Ao correr da pena”, Correio Mercantil. Rio de Janeiro, 8 jul. 1855, p. 1. Dois anos depois, José de Alencar escreveu a peça $O$ Crédito, representada pela primeira vez no Teatro do Ginásio do Rio de Janeiro em 28 de outubro de 1857, na qual o espírito especulativo desses anos foi tematizado.

(20) Este terceiro Banco do Brasil, com o capital de 30.000:000\$ (trinta mil contos de réis), veio a se instalar a partir da lei de 5 de julho de 1853, que punha em execução o projeto do Visconde de Itaboraí (Joaquim José Rodrigues Torres) de criar um banco nacional regulador do meio circulante do Império. Ele foi organizado com a fusão dos capitais do Banco Comercial do Rio de Janeiro com os do segundo Banco do Brasil, criado e instalado pelo Barão de Mauá a partir de 1851. 
A febre da agiotagem foi instituída pela distribuição das ações desse novo Banco do Brasil a prêmio de $10 \%$ sobre cada ação. Com um fim de utilidade pública - conseguir financiamento para realizar o calçamento da cidade do Rio de Janeiro - deliberou o Sr. Ministro da Fazenda, Marquês de Paraná (conselheiro Honorio Hermeto Carneiro Leão), que fosse distribuído um quinto do fundo de capital do novo Banco do Brasil na forma de 30 mil ações pelas pessoas que viessem a concorrer com $10 \%$ do seu valor nominal. Assim, 600 contos de réis foram divididos em 30 mil ações a $200 \$$ cada uma, postas à venda a juros por prêmio de $10 \%$ - rendendo, portanto, $20 \$ .^{21}$

Mesmo com toda a discussão realizada na época acerca da validade jurídica e dos efeitos deletérios ou benéficos para a economia do país dessa medida tomada pelo governo, a população carioca buscou freneticamente ter em mãos as ações do novo Banco do Brasil.

Em 1854, quando o Banco do Brasil ainda não estava instalado, a especulação das ações desse banco foi promovida por uma casa de câmbio que, defronte da praça do comércio, "era quartel-general da agiotagem, e centro d'onde partião telegraphicos avisos que, alterando rapidamente o mercado, reduzião muitas vezes á miseria os incautos compradores desses titulos e com elles suas infelizes familias." 22

E, se o fim desse terceiro Banco do Brasil era auxiliar o comércio, regularizando o meio circulante, a prática, no entanto, foi demonstrando que, regra geral, ele serviu principalmente para reunir dinheiro para dar aos banqueiros, que se estabeleceram como intermediários entre o comércio e o banco. Não obstante, $1854,1855,1856$ e 1857 foram anos em que muito se agitou na praça do Rio de Janeiro o jogo da agiotagem. Nesse jogo, muitos incautos sacrificaram as suas fortunas e os espertos bons capitais lucraram.

Das companhias anônimas aprovadas pelo governo imperial desde 1842 até 1864 , distinguindo as que se projetaram na Corte das que se organizaram para as províncias, perfaziam um total de 196, das quais 155 com capitais determinados, e 41 sem capitais fixos, dentre os quais se compreendiam as das estradas de ferro da Bahia, Pernambuco e São Paulo, cuja soma principal era formada por capitais ingleses.

Como já se assinalou, a maior parte das empresas e sociedades anônimas aprovada pelo governo imperial desde 1842 até 1864, cujas denominações vão ser

(21) Lei n. 683 de 5 de julho de 1853. Apesar de ter sido o mentor do terceiro Banco do Brasil, o Visconde de Itaboraí não presenciou a instalação desse banco por ter resignado o poder em setembro, sendo substituído pelo Marquês de Paraná, que seis meses depois pôs em funcionamento o banco, nomeando para seu presidente o conselheiro João Duarte Lisboa Serra.

(22) “Aviso aos incautos”, Jornal do Commercio. Rio de Janeiro, 6 jan. 1872, p. 2. 
apresentadas no mapa estatístico que segue abaixo, era organizada sem um plano ou estudo metódico e tinha, por fim principal, o jogo da agiotagem de suas ações.

\begin{tabular}{|c|c|c|c|c|c|c|}
\hline Anos & $\begin{array}{c}\text { Número } \\
\text { para a } \\
\text { Corte }\end{array}$ & $\begin{array}{c}\text { Número } \\
\text { para as } \\
\text { Províncias }\end{array}$ & $\begin{array}{c}\text { Número } \\
\text { Total }\end{array}$ & $\begin{array}{c}\text { Fundo de } \\
\text { Capital da } \\
\text { Corte }\end{array}$ & $\begin{array}{l}\text { Fundo de } \\
\text { Capital das } \\
\text { Províncias }\end{array}$ & $\begin{array}{c}\text { Fundo de } \\
\text { Capital Total }\end{array}$ \\
\hline 1842 & 2 & 1 & 3 & $5.400: 000 \$$ & 60:000\$ & $5.460: 000 \$$ \\
\hline 1843 & - & 1 & 1 & - & $2.000: 000 \$$ & $2.000: 000 \$$ \\
\hline 1846 & - & - & - & - & 400:000\$ & 400:000\$ \\
\hline 1847 & - & 2 & 2 & - & $600: 000 \$$ & $600: 000 \$$ \\
\hline 1851 & 4 & 3 & 7 & $12.000: 000 \$$ & $1.510: 000 \$$ & $13.510: 000 \$$ \\
\hline 1852 & 2 & 1 & 3 & $1.900: 000 \$$ & $300.000 \$$ & $2.200: 000 \$$ \\
\hline 1853 & 4 & -- & 4 & $9.300: 000 \$$ & --------------- & $39.300: 000 \$$ \\
\hline 1854 & 8 & 6 & 14 & $10.550: 000 \$$ & $4.000: 000 \$$ & $14.550: 000 \$$ \\
\hline 1855 & 13 & 8 & 21 & 52.888:000\$ & $4.370: 000 \$$ & $57.618: 000 \$$ \\
\hline 1856 & 9 & 4 & 13 & $23.340: 000 \$$ & $3.350: 000 \$$ & $26.890: 000 \$$ \\
\hline 1857 & 8 & 9 & 17 & $31.360: 000 \$$ & $5.382: 000 \$$ & $36.742: 000 \$$ \\
\hline 1858 & 8 & 9 & 17 & 19.400:000\$ & 24.025:000\$ & $43.425: 000 \$$ \\
\hline 1859 & 18 & 10 & 28 & 369.730:000\$ & 19.620:000\$ & $389.350: 000 \$$ \\
\hline 1860 & 4 & 5 & 9 & $3.140: 000 \$$ & 17.800:000\$ & $20.940: 000 \$$ \\
\hline 1861 & - & 3 & 3 & - & $1.900: 000 \$$ & 1.900:000\$ \\
\hline 1862 & 2 & 5 & 7 & $9.888: 000 \$$ & $1.850: 000 \$$ & $11.738: 000 \$$ \\
\hline 1863 & 1 & 2 & 3 & $10.000: 000 \$$ & $3.250: 000 \$$ & $13.250: 000 \$$ \\
\hline 1864 & 2 & - & 2 & $840: 000 \$$ & - & $840: 000 \$$ \\
\hline \multirow[t]{3}{*}{ Soma } & 85 & 70 & 155 & $389.936: 000 \$$ & 90.777:000\$ & 680.713:000\$ \\
\hline & & & & & $\begin{array}{c}\text { E mais } 41 \\
\text { Sociedades } \\
\text { sem Capital } \\
\text { prefixo }\end{array}$ & $50.000: 000 \$$ \\
\hline & & & & & Total & 730.713:000\$ \\
\hline
\end{tabular}

Fonte: Sebastião Ferreira SOARES, Elementos de Estatistica. Tomo I. Rio de Janeiro, Typographia Nacional, 1865, p. 247.

Pelo quadro acima, verifica-se o quanto foi aumentado o número de empresas anônimas estabelecidas na Corte e nas demais províncias do Império dos anos de 1854 a 1859. Das 155 sociedades anônimas instaladas de 1842 a 1864, 100 delas foram estabelecidas durante os anos de 1854 a 1859; e da soma total de 680.713:000\$, 566.575:000\$ foi a soma do fundo daquelas 100 sociedades anônimas aprovadas pelo governo imperial.

Verifica-se também, a partir de 1860, uma brusca diminuição da instalação das sociedades anônimas, como efeito da Lei n. 1083 de 22 de agosto de 1860, que cerceou a marcha das transações comerciais antes efetuadas sob o regime de ampla liberdade do crédito. Além dessa lei, há de se levar em conta os efeitos da crise dos Estados Unidos de 1857, que repercutiu aqui em 1858, fazendo falir 90 empresas na cidade do Rio de Janeiro - cuja soma do ativo e do passivo se 
elevou a 23.273:000\$; e em Pernambuco apareceram 4 quebras na importância do ativo e do passivo de 438:000\$.

De 1853 a 1862, o comércio do Rio de Janeiro era fundado principalmente sobre a ação do crédito, dispondo de um capital efetivo bem pequeno. Assim, as transações das permutas não repousavam sobre bases sistemáticas, que, mesmo realizadas em boa-fé, não apresentavam a menor probabilidade de solvência nas épocas determinadas pelas compras, ou pelas rendas.

Destarte, nesses anos as quebras ocorridas na praça do Rio de Janeiro começaram a ter maior intensidade, e a ser mais freqüentes desde que apareceram as empresas intentadas por associação anônima com capitais levantados a altos juros e, principalmente, assim que começaram a funcionar diversos bancos e associações bancárias na Corte. Os valores das falências comerciais, que ocorreram na praça comercial do Rio de Janeiro desde 1853 até 1863, são os que estão no quadro que segue.

\begin{tabular}{|l|c|c|c|c|c|}
\hline Anos & $\begin{array}{c}\text { Número dos } \\
\text { Falidos }\end{array}$ & $\begin{array}{c}\text { Balanço: } \\
\text { Ativo }\end{array}$ & $\begin{array}{c}\text { Balanço: } \\
\text { Passivo }\end{array}$ & $\begin{array}{c}\text { Prejuízo } \\
\text { Calculado: } \%\end{array}$ & $\begin{array}{c}\text { Prejuízo } \\
\text { Calculado: } \$\end{array}$ \\
\hline 1853 & 29 & $193: 000 \$$ & $206: 000 \$$ & $50 \%$ & $103: 000 \$$ \\
\hline 1854 & 37 & $562: 000 \$$ & $615: 000 \$$ & $50 \%$ & $307: 500 \$$ \\
\hline 1855 & 30 & $1.639: 000 \$$ & $1.817: 000 \$$ & $50 \%$ & $923: 500 \$$ \\
\hline 1856 & 27 & $1.642: 000 \$$ & $1.978: 000 \$$ & $50 \%$ & $989: 000 \$$ \\
\hline 1857 & 40 & $1.769: 000 \$$ & $1.753: 000 \$$ & $50 \%$ & $876: 500 \$$ \\
\hline 1858 & 90 & $10.510: 000 \$$ & $12.763: 000 \$$ & $50 \%$ & $6.381: 500 \$$ \\
\hline 1859 & 33 & $1.699: 000 \$$ & $1.575: 000 \$$ & $50 \%$ & $787: 500 \$$ \\
\hline 1860 & 43 & $3.281: 000 \$$ & $3.344: 000 \$$ & $50 \%$ & $1.672: 000 \$$ \\
\hline 1861 & 57 & $5.946: 000 \$$ & $6.821: 000 \$$ & $50 \%$ & $3.410: 500 \$$ \\
\hline 1862 & 104 & $8.118: 000 \$$ & $7.520: 000 \$$ & $50 \%$ & $3.760: 000 \$$ \\
\hline 1863 & 84 & $5.760: 000 \$$ & $3.736: 000 \$$ & $50 \%$ & $2.868: 000 \$$ \\
\hline Total & 587 & $41.112: 000 \$$ & $44.158: 000 \$$ & & $22.079: 000 \$$ \\
\hline
\end{tabular}

Fonte: Sebastião Ferreira Soares, Elementos de Estatistica. Tomo I. Rio de Janeiro, Typographia Nacional, 1865, p. 236.

Está claro que, no período de 1853 a 1863 , o ano de 1858 - como uma consequiência da crise de 1857 - foi o ano da maior quebra comercial até então existente na cidade do Rio de Janeiro. E já nesse ano de 1857, a casa bancária de Antonio José Alves Souto e Cia. sofreu o seu primeiro embate. Essa casa comercial, que depois viria a ser a principal responsável pela crise comercial de setembro de 1864, só não faliu em 1858 devido aos auxílios espontaneamente prestados pelos seus amigos e pelo crédito que lhe facultou o Banco do Brasil.

A partir desses anos, era perceptível que a conduta dos comerciantes cariocas havia mudado sobremaneira. Antes da publicação do Código Comercial, em 1850, e até 1852, era muito raro aparecerem questões judiciais por quebra dos 
contratos realizados; e ainda mais raro era o surgimento de uma falência comercial - o que levava o Barão de Mauá, como deputado à Assembléia Geral, na sessão de 1858, a afirmar, por ocasião de se tratar da reforma bancária apresentada pelo Conselheiro Salles Torres Homem, que não conhecia, nem tinha "noticia de praça comercial alguma, na qual houvesse mais honestidade, boa fé e honradez, que nos comerciantes do Rio de Janeiro". Mas a partir de então tudo se inverte para a máfé e o calote. Era o tempo de ganhar dinheiro a todo transe, tornando-se legítima a suspensão de todas as garantias da honra, do justo e do honesto; em que se podia sem escrúpulos violar os princípios da probidade, amizade e consciência.

O capital negreiro que foi reciclado para o sistema monetário brasileiro instalado na Corte Imperial também financiou o tráfico inter-regional. Se, antes da proibição do tráfico, ao fazendeiro era facultado o pagamento dos escravos adquiridos em forma de escambo (café, aguardente, animais e mesmo terra), depois da cessação do tráfico os escravos adquiridos no Norte do país eram pagos em moeda.

O tráfico de escravos inter-regional movimentou vultosas somas de capital. Um observador financeiro escreveu, em junho de 1853, "que quantias importantes em papel e metal teem sido enviadas para a compra de escravos aos bazares do Norte, o qual, depois da cessação do trafico, transformou-se para os plantadores do Sul em uma nova costa da Guiné". ${ }^{23}$ Os efeitos disso fizeram-se sentir até no Maranhão. Conforme salientava Henrique Leal, no fim da década de 1850 notava-se claramente a existência de uma inflação e carestia gerais em um quadro social em que os salários aumentavam, pois o operário ganhava o dobro, a fortuna pública e a particular cresceram, e a procura de todas as coisas não tinha limites; tudo isso impulsionado pela abundância de moeda. ${ }^{24}$

A rápida cessação do tráfico transatlântico de africanos escravos para o Brasil deixou os lavradores ${ }^{25}$ em apuros. Privados da fonte de abastecimento externo, a todo custo eles começaram a recorrer aos povoados a fim de se proverem dos escravos de que precisavam para suas lavouras. Ao mesmo tempo, começaram a se avolumar e tornar freqüentes as transações de escravos originários das províncias do Norte, os quais viam-se dirigidos para o Sul do Império, onde

(23) “A crise da praça II", Correio Mercantil. Rio de Janeiro, 21 jun. 1853, p. 1. O Ministro da Fazenda, Paraná, no seu relatório de 8 de maio de 1855, afirmava que o recém-criado Banco do Banco não estava conseguindo manter os seus fundos, pois "avultadas quantias em metal e papel-moeda para compra de safras e escravos no Norte, e para outros diversos destinos, produziram no mercado um vazio que dificultava ao Banco a conservação do seu fundo disponível (...)". Sobre os efeitos desse tráfico na organização bancária e na contabilidade do fazendeiro do Sul, ver Granziera (1979, p. 15-17).

(24) Antonio Henriques Leal, Locubrações. Lisboa: Typographia Castro Irmão, 1874, cap. "Questões economicas e administrativas", p. 295-318.

(25) Mello (1999, p. 12), no léxico imperial “'lavoura' significava exclusivamente a grande lavoura de exportação". 
eram comprados pelos fazendeiros. ${ }^{26}$ Em sua maior parte, os escravos foram vendidos pelas províncias do Norte para saldar dívidas dos seus lavradores. ${ }^{27}$ Chegados ao Rio de Janeiro, os escravos do Norte eram comprados pelos fazendeiros do Sul. A tabela que segue demonstra o número dos escravos importados da África e dos que foram vendidos do Norte para o Rio de Janeiro.

\begin{tabular}{c|c|c|c}
\hline \multicolumn{2}{c|}{ Importados da África } & \multicolumn{2}{c}{ Remetidos do Norte para o Sul do Império } \\
\hline 1840 & 30.000 & 1852 & 4.409 \\
\hline 1841 & 16.000 & 1853 & 2.909 \\
\hline 1842 & 17.435 & 1854 & 4.418 \\
\hline 1843 & 19.095 & 1855 & 3.532 \\
\hline 1844 & 22.849 & 1856 & 5.006 \\
\hline 1845 & 19.463 & 1857 & 4.211 \\
\hline 1846 & 50.324 & 1858 & 1.993 \\
\hline 1847 & 56.172 & 1859 & 963 \\
\hline 1848 & 60.000 & & \\
\hline 1849 & 54.000 & & \\
\hline 1850 & 23.000 & & 27.441 \\
\hline 1851 & 3.287 & & Total \\
\hline Total & 371.625 & & \\
\hline
\end{tabular}

Fonte: Sebastião Ferreira Soares, Elementos de Estatistica. Tomo I. Rio de Janeiro, Typographia Nacional, 1865, p. 228.

Com respeito ao volume do tráfico inter-regional, retirado dos registros da polícia da Corte do Rio de Janeiro, em números transcritos por Sebastião Ferreira Soares e reproduzidos acima, deve-se levar em conta que neles não constam verdadeiramente todos os escravos provenientes do Norte, pois certamente aqueles números não representavam nem os escravos que vinham com os seus senhores a título de mudança, e nem os escravos que com certeza eram transacionados sem expressa declaração de sua venda, para que não fosse pago o imposto (a meia sisa) cobrado pelo governo na transferência de posse de escravo. Não seria, então, excessivo, alegava Ferreira Soares, juntar-se aos números de cima mais 50\%, perfazendo uma média de 5.195 escravos anualmente deslocados das províncias

(26) Em seu estudo sobre a economia e a sociedade cafeicultora na parte ocidental do Vale do Paraíba da segunda metade do Oitocentos, Stein (1961, p. 35) escreveu que "conquanto o esto do tráfico negro tenha possibilitado a rápida expansão da cultura cafeeira durante a década anterior, foi a cessação dêsse mesmo tráfico que incentivou a prosperidade e a opulência. Para as pequenas fazendas, com poucos escravos, a vertiginosa alta de preço do escravo, depois de 1852, constituiu verdadeira calamidade. Ao contrário, para os grandes fazendeiros que haviam contraído dívidas no período de preços baixos, a terminação do tráfico constituiu uma bonança. Em conseqüência dessa valorização dobrou também o valor das garantias que podiam oferecer para contrair novos empréstimos, que iriam permitir-lhes superar a primitiva economia de autosuficiência característica da primeira fase agrícola".

(27) Também de acordo com Mello (1999, p. 64-65), os "grandes beneficiários [dos lucros decorrentes do tráfico inter-regional de escravos do Norte para o Sul] foram aqueles que o promoviam e controlavam, isto é, comerciantes das capitais nortistas, mas, sobretudo, comerciantes da Corte". 
do Norte para a cidade do Rio de Janeiro; e se ainda a estes se juntassem pelo menos 304 escravos vindos todos os anos de Minas e do Rio Grande do Sul, a soma dos escravos importados anualmente na cidade do Rio de Janeiro se elevaria a $5.500 .^{28}$

Foi esse movimento de reposição da força de trabalho que originou os crescidos débitos dos lavradores, contraídos a altos juros. Enquanto em 1846 um escravo era comprado por $500 \$ 000$ a $600 \$ 000,{ }^{29}$ de 1852 a 1859 o preço de um escravo moço e robusto oscilou entre 1:000\$000 e 2:000\$000..$^{30}$ Multiplicando os 27.441 escravos pelo preço médio de 1:500\$ cada um, verificar-se-á que os escravos importados do norte do Império para a província do Rio de Janeiro representaram um valor de 41.161:500\$. E tal valor, como veremos abaixo, representa a importância da dívida da hipoteca rural e de seus acessórios das províncias do Rio de Janeiro, Minas Gerais, São Paulo e Rio Grande do Sul, que somava naquela época 35.799:795\$000.

Além das províncias do Rio de Janeiro, São Paulo e Minas, lugares que em maior escala cultivavam o café, e do Rio Grande do Sul, grande fornecedor de produtos comestíveis para o mercado interno, as províncias da Bahia e de Pernambuco, dois grandes exportadores de açúcar, também tiveram elevadas as suas dívidas de hipoteca rural.

Os prêmios dos dinheiros tomados sobre hipotecas eram no período bastante excessivos, computando, termo médio anual, acima de $18 \%$, havendo algumas hipotecas com o prêmio de $2,5 \%$ a $5 \%$ ao mês. E isso, quando os juros bancários giravam em torno de $4 \%$ a $6 \%$ anualmente! Foi a própria dinâmica da indústria agrícola e exportadora que empurrou os produtores rurais a se submeterem a tal usura nesse momento.

(28) A partir de uma estatística de Liverpool sobre a importação de escravos africanos feita pelo Brasil de 1840 a 1851, transcrita na tabela acima, Soares (1860, p. 134-135), deduzia "que o termo médio dos escravos importados da Costa d'Africa nos onze annos decorridos de 1840 a 1850, visto que o de 1851 foi o da extincção do tráfico, eleva á somma de 33,482 por anno. Calculando-se que destes 33,482 ficavão nas cidades e povoados sómente 1/3 (que muito mais devião ficar), teremos para a lavoura 22,160 escravos; é preciso, porém, observar que pelo menos uma terça parte destes era ceifada por molestias e pelas fugas, pelo que, no fim de tres annos (tempo necessario para industria-los), sendo muito felizes os lavradores, podião contar com 14,774 escravos para a lavoura. Não exagero este calculo, porque sou informado que o fazendeiro que comprava 100 captivos, calculava tirar no fim de tres annos 25 escravos para o seu serviço. Distribuindo estes 14,774 captivos para todo o Brazil, quero suppôr que ás provincias do Rio de Janeiro, Minas, S.Paulo e Rio Grande do Sul coubessem 7,387 annualmente". No seu entender, então, aquela média de 5.500 compensava a extinção do tráfico negreiro, porque "eles seguiam imediatamente para a lavoura".

(29) Esse valor foi pronunciado pelo deputado J. Nunes Machado na sessão da Câmara dos Deputados realizada em 4 de julho de 1846. Cf. Jornal do Commercio. Rio de Janeiro, 5 jul. 1846, p. 1.

(30) Números fornecidos por Soares (1865, Tomo I, p. 228). De acordo com Buescu (1970, p. 244-249), entre 1845 e 1855 , o preço médio dos escravos cresceu $155,6 \%$. 
De acordo com a estatística organizada pelo Ministério da Justiça, em 1859 esses altos juros da dívida de lavradores e comissários fizeram avultar a dívida hipotecária do Império, conforme pode ser observado no quadro que segue, conforme as suas respectivas províncias:

Dívida hipotecária do Império a partir de 1855 até o ano de 1859

\begin{tabular}{|c|c|c|c|c|}
\hline Províncias & Urbana & Rural & $\begin{array}{c}\text { Sobre bens } \\
\text { diversos }\end{array}$ & Total \\
\hline Município Neutro & $11.231: 495 \$$ & $913.256 \$$ & $5.051: 660 \$$ & $17.196: 411 \$$ \\
\hline Rio de Janeiro & $3.142: 206 \$$ & $13.568: 241 \$$ & $4.813: 046 \$$ & $21.523: 493 \$$ \\
\hline Amazonas & $60: 008 \$$ & $3: 080 \$$ & $2: 753 \$$ & $65: 841 \$$ \\
\hline Pará & $783: 511 \$$ & $284: 827 \$$ & $108: 278 \$$ & $1.176: 616 \$$ \\
\hline Maranhão & $419: 883 \$$ & $409: 378 \$$ & $310: 710 \$$ & $1.139: 971 \$$ \\
\hline Rio Grande do Norte & $42: 541 \$$ & $83: 166 \$$ & $22: 560 \$$ & $148: 367 \$$ \\
\hline Paraíba & $120: 179 \$$ & $185: 085 \$$ & $132: 701 \$$ & $437: 965 \$$ \\
\hline Pernambuco & $879: 440 \$$ & $912: 430 \$$ & $602: 298 \$$ & $2.394: 168 \$$ \\
\hline Alagoas & $103: 885 \$$ & $143: 083 \$$ & $117: 472 \$$ & $364: 440 \$$ \\
\hline Sergipe & $251: 645 \$$ & $404: 370 \$$ & $136: 567 \$$ & $792: 591 \$$ \\
\hline Bahia & $2.983 .709 \$$ & $2.360: 284 \$$ & $567: 746 \$$ & $5.911: 739 \$$ \\
\hline Espírito Santo & $110: 571 \$$ & $202: 983 \$$ & $57: 524 \$$ & $371: 078 \$$ \\
\hline São Paulo & $1.161: 408 \$$ & $3.305: 314 \$$ & $707: 517 \$$ & $5.474: 239 \$$ \\
\hline Paraná & $93: 755 \$$ & $121: 241 \$$ & $130: 935 \$$ & $343: 931 \$$ \\
\hline Santa Catarina & $180: 247 \$$ & $165: 518 \$$ & $19: 055 \$$ & $364: 820 \$$ \\
\hline Rio Grande do Sul & $1.566: 406 \$$ & $1.251: 377 \$$ & $1.860: 951 \$$ & $4.678: 734 \$$ \\
\hline Goiás & $23: 844 \$$ & $828 \$$ & $45: 850 \$$ & $70: 522 \$$ \\
\hline Minas Gerais & $396: 987 \$$ & $2.490: 073 \$$ & $1.838: 360 \$$ & $4.725: 420 \$$ \\
\hline Mato Grosso & $78.673 \$$ & $7: 380 \$$ & $28: 220 \$$ & $114: 273 \$$ \\
\hline Piauí & $61: 860 \$$ & $71: 943 \$$ & $67: 648 \$$ & $201: 451 \$$ \\
\hline Ceará & $121: 592 \$$ & $444: 802 \$$ & $108: 563 \$$ & $674: 957 \$$ \\
\hline Total & $23.813: 843 \$$ & $27.328: 759 \$$ & $16.730: 423 \$$ & $67.873: 027 \$$ \\
\hline
\end{tabular}

Como se vê na tabela acima, a dívida de hipoteca rural se elevava na província do Rio de Janeiro à soma de 13.568:241\$, e para o município da Corte 913:256\$, perfazendo 14.481:497\$. E as dívidas de hipoteca rural nas províncias de São Paulo e de Minas Gerais eram, respectivamente, 3.305:314\$ e 2.490:073\$. Pessoas bem informadas do período calculavam que em 1865 essa dívida já estaria acima de 40.000:000\$. Tendo em vista que a soma total da dívida hipotecária do Brasil de 1855 a 1859 era de 67.873:027\$000, contraída em 5 anos ao juro médio anual de $18 \%$, Sebastião Ferreira Soares afirmava que tal situação era, por si só, capaz de gerar uma enorme crise no país, pois a dívida:

revela a plena luz a mais requintada usura por parte dos mutuantes, e da dos mutuarios o abandono total de toda previsão e economia; portanto, ainda mesmo fazendo-se uma amortização anual de 20 por cento do capital e juros (como se 
deduz dos dados officiaes do ministerio da justiça, que servem de base, os quaes demonstrão que do emprestimo contrahiudo de 1855 a 1859 se tinhão amortizado 6.970:812\$000), semelhante emprestimo é por demais ruinoso, visto que, para se realizar a amortização demonstrada, foi preciso pagar aos mutuantes, em cinco annos, a enorme somma de 65.117:744\$, e ainda ficarem devendo os mutuarios 60.902:215\$ (Soares, 1865, Tomo I, p. 228-229).

Mas o fazendeiro também não poderia se tornar um rentista, e pôr o patrimônio a ganhar juros na maior praça comercial do país? Haveria algum impedimento legal, material ou moral para tal intento? Enfim: existia alguma diferença em se ganhar dinheiro através da produção, da renda da terra, do aluguel, do empréstimo, do salário, etc.? Era nesse sentido que um anônimo fazia as seguintes perguntas, publicadas no Correio Mercantil de 13 de outubro de 1853:

Se um homem que vende a sua fazenda agricola, e vem para a côrte, e distribue seus capitaes a premio, e arrenda cortiços, edifica outros, se é ou não é negociante, ou se negociante só é aquelle de porta aberta? Emfim quero saber se é ou não negociante aquelle que distribue seus capitaes e rendimentos, sendo o seu ramo de vida. $^{31}$

Afinal de contas, por meras questiúnculas morais, não valeria a pena correr riscos à toa! Além disso, para os produtores agrícolas ainda havia presente um outro mal, que caberia não esquecer, do perigo que corriam os estabelecimentos rurais de um dia para outro diminuírem de preço e de importância, pois o valor das propriedades dependia dos braços escravos. De um ano para outro, de um dia para outro, causas acidentais e extraordinárias podiam despojá-los dos braços que possuíam.

Diante dos três fatores da produção - o trabalho, o capital e a terra -, este último estava estruturalmente inter-relacionado com o primeiro, pois sem o fator trabalho (nesse momento histórico, trabalho compulsório) a terra não possuía nenhum valor, e dela também não era extraída nenhuma renda. A propriedade da terra em si nada valia, pois ela somente passava a ser fator de produção se, e somente se, nela existisse o fator trabalho para lhe atribuir valor. Já a renda da terra só passaria a ocorrer quando o outro fator de produção - o capital financiasse a montagem da economia agrícola. Está, portanto, estabelecido o mecanismo cuja gênese, dinâmica e direção é determinada pelo capital mercantil, pois não só a mobilização dos recursos produtivos, mas também toda a economia agrícola - sobretudo a exportadora - adquiriu um caráter intrinsecamente mercantil.

Em 1856, um crítico do sistema financeiro brasileiro afirmava que, enquanto o comércio da Corte tomava dinheiro emprestado a $2 \%$ acima da taxa

(31) "Quem pergunta quer saber", Correio Mercantil. Rio de Janeiro, 13 out. 1853, p. 2. 
Política, agricultura e a reconversão do capital do tráfico transatlântico de escravos para as finanças brasileiras...

dos descontos dos bancos, a lavoura pagava $4 \%$ acima da taxa dos bancos da Corte. Tal situação, esclarecia, era porque

no commercio da praça do Rio de Janeiro, que paga $2 \%$ acima da taxa dos bancos, estão comprehendidos consignatarios de café que possuem 200:000\$ a 600:000\$ de fundos, recebem á consignação annualmente 200 a 900.000 arrobas de café, e realisão por conseguinte operações annuaes de 1 a 2.000:000\$.

E em consequencia de os consignatarios de café obterem o dinheiro a $2 \%$ acima da taxa de descontos e a curtos prazos de 4 mezes, a lavoura da provincia do Rio de Janeiro, que é em grande parte devedora a esses consignatarios, paga a dinheiro na praça do Rio de Janeiro a maiores prazos, na razão de $4 \%$ acima da taxa dos bancos. $^{32}$

O sistema de financiamento e de crédito que possibilitou que as taxas de juros para o setor agrícola fossem mais elevadas quando comparadas aos juros cobrados para o comércio, foi implementado pelo Partido Conservador após a reconversão do capital negreiro para a praça comercial do Rio de Janeiro. Conforme dados elaborados por Ridings, na região sul imperial, as taxas de juros para o crédito variam de $6 \%$ a $10 \%$ anuais para as casas comerciais, e de $8 \%$ a $14 \%$ para os agricultores. No Norte, as taxas subiam de $9 \%$ a $18 \%$ para as empresas de comércio, e de $18 \%$ a $24 \%$ para os agricultores (Ridings, 1994, cap. 5).

Após a crise comercial de 1857, a situação piorou, pois o dinheiro ficou mais escasso e caro. Nesse momento, um contemporâneo (e provável fazendeiro do Vale do Paraíba) fazia as seguintes observações:

Todos sabem da escassez de dinheiro que há na praça, e dos apuros em que ella se acha. Todos os titulos de valores têm cahido tão baixo como nunca.

Há no meio de tudo isto uma calamidade maior: os nossos lavradores não podem obter, senão com muitissima difficuldade, a mais insignificante quantia para acudirem ás suas necessidades; os bancos que ora funccionão não lhes servem de nada; não aceitão os bens que elles podem dar em garantia; e os capitalistas não dão o seu dinheiro para o interior, ainda mesmo para o premio de $18 \%$, quando aqui é procurado a 14 e 15 e mais!

Os balancetes mensaes dos bancos comprovão o que dissemos; para o commercio tudo pois, e para a lavoura nada.

Entretanto, nessa critica situação grande beneficio teria o governo feito se há mais tempo tivesse consentido na approvação daquelles estabelecimentos de credito, que por sua organisação especial são os unicos capazes de favorecer nossos agricultores de seus proprios bens.

(...) A lavoura tem pois necessariamente de se arruinar; os agricultores se achão no maior apuro; notão com immenso pezar que se os cofres publicos estao recheados, dahi não lhes vem o minimo proveito, lamentão do fundo da alma que parte desse

(32) "Reflexões sobre os bancos de emissão. Bancos brazileiros. II.", Jornal do Commercio. Rio de Janeiro, 15 nov. 1856, p. 2.

Economia e Sociedade, Campinas, v. 17, n. 3 (34), p. 463-491, dez. 2008. 
dinheiro seja antes empregado em robustecer a sanguinolenta ferocidade de povos turbulentos, que sempre forão e hão de ser nossos eternos inimigos. ${ }^{33}$

Nesse período, o capital produtivo, sobretudo agrícola, estava no palco do país para representar a pujança do capital mercantil urbanizado. Atado ao leito de Procusto do capital mercantil, o setor produtivo rural podia no máximo gritar contra a situação na qual se encontrava, mas era claro que esse setor estava preso à dinâmica de retração ou de expansão imposta ou permitida pelo capital mercantil urbanizado. Assim, se antes a sua expansão era garantida pela ampla liberdade do crédito, depois ocorreria a retração diante dos juros e amortizações dos empréstimos contraídos e até a ruína diante da obrigação do desembolso em curto prazo.

Os agricultores dificilmente encontravam as somas necessárias para o custeio de suas fazendas e para a aquisição de instrumentos, máquinas e o que mais era de importância para seu melhoramento. Eles somente as podiam adquirir com sacrifícios enormes, pois, em algumas províncias, os contratos eram convencionadamente realizados sob juros muito mais altos que os cobrados pelos bancos.

Como vimos acima, os prêmios dos dinheiros tomados pelo setor rural sobre hipotecas também eram no período bem altos, computando, termo médio anual, acima de $18 \%$. Além disso, os lavradores pagavam gravosos juros aos comissários, nunca menores que $12 \%$ ao ano. ${ }^{34}$

Os cartórios, os livros de notas e os processos que se promoviam na época revelam a penúria dos agricultores, os sacrifícios e perdas de muitos, e até alguma total ruína e miséria deles. Na própria Corte eram apontados os capitalistas que levantaram riquezas colossais através de empréstimos concedidos à lavoura. Os mistérios que envolviam a história dessas riquezas revelavam a penúria e desgraça de um sem-número de lavradores.

Mas por que os lavradores ficavam presos a juros tão onerosos que causavam uma avultada despesa nos seus encargos? Em outras palavras: qual era o mecanismo que obrigava o produtor agrícola a se submeter a juros tão altos, sendo claro que a usura era um mal que lhe roía as entranhas?

Apesar de, para muitos, parecer à primeira vista ser a terra a coisa mais segura do mundo, para os contemporâneos ela não inspirava nenhuma confiança, fornecendo fraco penhor, e era a garantia que mais se repelia.

(33) "A crise e a lavoura”, Jornal do Commercio. Rio de Janeiro, 8 jun. 1858, p. 2.

(34) A informação sobre os juros anuais cobrados pelos comissários está em Soares (1865, Tomo I, p. 215 , nota 8 ). 
Para conseguir realizar um crédito rural junto a bancos ou casas comerciais, o lavrador precisava transpor vários obstáculos de ordem legal. Por ser a legislação civil do período demais defeituosa pela sua grandeza, extensão e complicação da matéria, no que tocava aos bens de raiz, aos diferentes modos de sua aquisição, transmissão, garantia, ônus, obrigações, sobrempeceria a marcha e criaria vários embaraços para o lavrador que precisava adquirir capitais necessários para o seu melhoramento.

Além desses males, havia mais outros que traziam ainda mais dificuldades, amofinações e riscos a quem se aventurava emprestar dinheiro aos lavradores. Conforme apontava o desembargador J. R. Brito:

A demora dos processos, em virtude das dilatações fataes de outros termos creados pelas leis e inventados pela fraude, a incerteza dos julgamentos, as difficuldades que se levantão em sua execução, o trabalho, cuidados e amofinações que requer uma lide, ainda que por natureza seja simples, os gastos que absorvem as taxas a que estão sujeitos os processos civeis, são por certas razões ponderosas para que ainda com menores vantagens o capitalista prefira outro ramo de industria que não a lavoura para o emprestimo de seus fundos, ou que exija premios a juros excessivos que de algum modo compensem os riscos de seus capitaes. ${ }^{35}$

Não obstante, tais dificuldades, amofinações e riscos subiam de ponto quando os devedores pertenciam a certa classe de lavradores privilegiada ou por força das leis, ou pela posição que estes tomavam nos lugares que habitavam.

Difficil é achar um procurador, um solicitador, ou um advogado, que tome sob sua protecção e cobrança de certas dividas e a execução de certos devedores, cujo numero infelizmente vai em augmento nestes ultimos tempos em certas provincias. No caso de encontrar-se um temerario que se arrisque a tomar sobre seus hombros esse encargo, grande pena dá-se na procura $-1^{\circ}$, de um juiz de paz; $2^{\circ}$, de outros juizes; $3^{\circ}$, de escrivães; $4^{\circ}$, de officiaes; e até os collectores por mil modos se excusão ou de sellar os documentos e as folhas de autos, e o pregoeiro da accusação das citações ou da publicação dos editaes, e do pregão dos bens se esquiva ao desempenho de seus deveres. Molestias, impedimentos, suspeições são os recursos ordinarios em taes conjuncturas, e ás vezes, o foro pára, as audiencias se adião, as praças se demorão, e os leilões correm sem licitantes ou os processos somem-se, e se inutilisão. Milhares de exemplos se poderião disto apontar (....). ${ }^{36}$

E se, na capital do Império, isso de dava, nos lugares mais afastados e mais destituídos de proteção administrativa os ressaibos de agravos aumentavam ainda mais. Nos lugares de residência dos lavradores, em que as posições administrativas e judiciais eram pela maior parte das vezes ocupadas pelos próprios lavradores e seus parentes, ou subordinados, tornava-se muito difícil

(35) "Reforma das alfandegas. XXVII. Falta de capitaes e obstaculos que encontra o crédito rural. § I. Das leis relativas á organização judiciaria, ao processo civil, e aos privilegios de que gozão certa classe de lavradores", Jornal do Commercio. Rio de Janeiro, 10 nov. 1853, p. 2.

(36) Idem. 
encontrar juiz de paz capaz de levar a cabo um processo sem que seus empenhos gerassem suspeições em prol dos lavradores.

Além daquelas posições administrativas e judiciais - reguladas pela moeda eleitoral - existiam ainda alguns privilégios gozados pelas lavouras e proprietários de engenhos de açúcar. ${ }^{37}$ De acordo com esse privilégio, em caso de não-pagamento de dívidas contraídas por proprietários de fábricas de açúcar, as lavouras e propriedades do engenho não poderiam ser executadas quando o valor da dívida não fosse superior à metade do seu valor e do valor dos objetos que eram inerentes ao seu cultivo e custeio, e somente uma terça parte do seu rendimento. Por tornar incerta a cobrança das dívidas, esse privilégio dava azo a mil abusos que dificultavam o fornecimento e empréstimos de dinheiro aos agricultores.

Num efeito perverso, em vez de melhorar a situação dos proprietários, aquele privilégio piorou as condições dos lavradores donos de engenhos produtores de açúcar, pois eles não conseguiam achar capitais pelo juro corrente da praça. Por essa razão, viam-se na necessidade de tomá-los com grandes sacrifícios, por altos prêmios, e a se submeterem às condições as mais duras e penosas. Em todas as transações que tinham por base, ou versavam sobre bens de raiz, as questões que preocupavam os capitalistas eram as seguintes:

Serão estes bens de raiz proprios? Seu dominio é contestado ou se acha seguro? Achão-se livres e desembargados? Qual o seu verdadeiro valor? Em que consiste este valor? Acaso pôde dar-se a sua diminuição? ${ }^{38}$

O empréstimo junto a capitalistas obrigava os lavradores a provar que possuíam legalmente bens suficientes (terras + escravos) para cobrir o valor do crédito a seu favor. Porém, além de causas acidentais e extraordinárias que poderiam despojar o agricultor dos braços que possuía, e assim desvalorizar sobremaneira o seu patrimônio rural, havia também a má-fé por parte do produtor rural. O lavrador podia tirar a flor da sua escravaria e passá-la a terceiros. ${ }^{39}$ No momento da execução do empréstimo - depois de firmado o compromisso - podia esconder parte da escravaria, ou vendê-la simuladamente.

(37) Privilégio dado pela resolução de 22 de setembro de 1758, provisão de 26 de abril de 1760, alvará de 6 de junho de 1807 e de 21 de janeiro de 1809.

(38) "Reforma das alfandegas. XXVII. Obstaculos que encontra o crédito rural. § II. Leis sobre hypothecas e da falta da publicidade destas", Jornal do Commercio. Rio de Janeiro, 12 nov. 1853, p. 1-2 (citação p. 1).

(39) Conforme escrevia-se no momento: "póde por outro lado um mal epidemico ceifa-la [a escravaria], e o capitalista perder essa garantia e seus capitais. E não se esqueça que nem os nomes dos escravos, nem as providencias policiaes podem dar garantia contra a fraude; porque é sobremodo facil mudar aquelles e inutilisar estes, attenta a natureza e extensão do nosso territorio, e sobre exemplo de nossa propria lavra (...)." "Reforma das alfandegas. XXVII. Obstaculos que encontra o crédito rural. § IV. Leis fiscaes, e impostos", Jornal do Commercio. Rio de Janeiro, 15 nov. 1853, p. 1. 
Política, agricultura e a reconversão do capital do tráfico transatlântico de escravos para as finanças brasileiras...

Por um abuso e falta de fé que cumpre condemnar ao ferrete da infamia, muitos capitalistas de boa fé tem sido victimas de muitos lavradores, que em suas avenças não se portão como lhes cumpre. Outros tem sido sacrificados em virtude de burlas e outros meios fraudulentos. Tem-se dado até casos em que lavradores tratando a remessa de sua colheita com seus correspondentes, mudão as marcas dos volumes de seus productos que remettem para as praças commerciais, para que estes não conheção os que lhes são pertencentes, e os consigão a outros, faltando assim aos seus compromissos.

Por estas e outras artes, para remirem suas necessidades, para retardarem a catastrophe que talvez os ameaça, procurão os lavradores illudir os capitalistas no tocante ao estado de seus negocios e haveres; e estes para evitarem o naufragio de que tem sido victimas os de sua classe, na desconfiança que geralmente lavra contra as avenças e empenhos dos agricultores, por meio de altos e exorbitantes juros, de clausulas e condições ainda mais exorbitantes, procurão abroquelar-se contra a fraude, e obrigar-se do risco e da perda que temem, e muitas vezes nem as cautelas as mais robistas, nem seus calculos usuarios, nem os juros capitalisados os tem podido salvar.

Daqui a grande difficuldade dos emprestimos, a ruina de muitos lavradores, e penuria da lavoura; pois que a maior ou menor facilidade dos emprestimos, as condições favoraveis com que estes se obtem sempre, e em toda parte, estão na razão de maior ou menor gráo de segurança da divida e celeridade do seu pagamento. $^{40}$

Os lavradores tinham de aceitar descontos de letras de terra, de assinados das alfândegas, de bilhetes, letras e outros títulos do governo a prazo certo, o depósito de fundos e objetos de valor, o empréstimo sob caução de qualquer natureza, inclusive o penhor e a hipoteca, e a emissão de letras ou vales até certa quantia, tudo com vencimentos em curto prazo e com altos juros predeterminados.

Se a usura decorrente dos altos juros é um cancro que aleija para quem precisa de crédito a fim de expandir os seus negócios, no caso da lavoura a obrigação do desembolso em curto prazo é um câncer que mata. Essa obrigação, aliada aos encargos sobremodo onerosos, e após si e em breve termo a desapropriação por via executiva no caso de não-pagamento do crédito realizado e isso para os lavradores que tinham como provar o domínio e posse dos bens de raiz - afugentava os agricultores de estabelecer qualquer negócio diretamente com os estabelecimentos bancários ou casas comerciais.

Avaliava-se, desse modo, que a realização de qualquer empréstimo ao lavrador era considerado um empréstimo de risco. E, por conta desse risco, os juros dos empréstimos realizados pelos comissários aos fazendeiros eram muito acima dos juros normalmente cobrados pelos bancos e casas comerciais nas praças comerciais instalados nos principais centros urbanos.

(40) "Reforma das alfandegas. XXVII. Obstaculos que encontra o crédito rural. § II. Leis sobre hypothecas e da falta da publicidade destas", Jornal do Commercio. Rio de Janeiro, 12 nov. 1853, p. 1-2 (citação p. 1).

Economia e Sociedade, Campinas, v. 17, n. 3 (34), p. 463-491, dez. 2008. 
Não obstante, para que tornasse duradoura a relação estabelecida entre emprestador e devedor, um laço de recíproca confiança precisava ser estabelecido entre fazendeiro e comissário. Desse modo, não seria exagero afirmar que o casamento de negócios entre fazendeiro e comissário estava afiançado sobre a confiança que sentiam um pelo outro. Mas essa confiança apresentava um alto preço, revelando qual seria o destino dos fazendeiros presos às hipotecas e aos comissários: ambos estavam fadados a falir. ${ }^{41}$

O casamento forçado entre fazendeiro e comissário foi arranjado e patrocinado pelo capital mercantil urbanizado, que, como presença onipotente e ao mesmo tempo sequioso pelos altos rendimentos assegurados através desse enlace entre lavoura e meio circulante, mostrava o quanto os senhores do crédito e do comércio dominavam a fazenda, o engenho e o latifúndio.

A par disso, esclareça-se, entretanto, que a expansão cafeeira continuou no Vale do Paraíba fluminense entre 1850 e 1881, com a incorporação de uma crescente escravaria. ${ }^{42}$ Mas se as dificuldades econômicas dos anos 1850 e início dos anos 1860 pareciam atenuadas, a crise bancária de 10 de setembro de 1864 não limitou os seus funestos resultados à época em que se deu; pelo contrário, os seus efeitos fizeram-se sentir por muito tempo. Decorridos dez anos, indagava-se, ainda para conjurar essa crise financeira, o que havia sido feito "no sentido de beneficiar a lavoura opprimida e acabrunhada por todas as formas?..."

Creou-se uma caixa hypothecaria no Banco do Brazil com um fundo de 35:000.000\$000 reis, com o fim especial de auxiliar a lavoura, sendo contemplados de preferencia os estabelecimentos agricolas que já erão devedores ao Banco. Immobilisou-se esta grande somma improficuamente, porque, deixou-se a lavoura no mesmo circulo vicioso em que tinha girado até alli, com os mesmos defeitos e onerada com os mesmo encargos.

E a prova de nenhuma utilidade da creação da caixa hypothecaria, é que, á proporção que as hypothecas se vencião, o Banco ia tomando conta das repectivas fazendas.

Sempre nos pareceu que não era mister mais esta prova, para justificar que a lavoura do Brazil, não pode supportar um juro de 10\%, juro, e amortização de 5\% pagos de seis em seis mezes. ${ }^{43}$

(41) Convém esclarecer que a falência de comissários e fazendeiros do Vale do Paraíba fluminense e paulista era fruto da relação entre pequenos e médios produtores agrícolas com os comissários donos de capitais médios. Cf. Ferreira (1977). Os grandes cafeicultores (nas contas de Sweigart, 1980, p. 66-98, pelo menos 1/6 de todos os sócios de firmas de corretagem do Rio de Janeiro eram fazendeiros de café do interior) diversificavam o seu capital, integrando-se ao alto comércio comissário.

(42) Slenes (1986, p. 103-151), mostrou a manutenção e o dinamismo econômico e, especialmente, da população escrava no Vale do Paraíba fluminense até 1880.

(43) “A situação commercial”, Revista da Associação dos Guarda-Livros. Rio de Janeiro, v. 1, n. 11, 30 nov. 1874 , p. 1. 
Dessa forma, os fazendeiros fluminenses ainda dispunham de acesso ao crédito no final da década de 1870 , pois nesse período houve uma transformação das formas de financiamento da cafeicultura, com a expansão do crédito hipotecário e bancário até a década de 1880. Mas no ano de 1885 , em meio às discussões ocorridas na assembléia a partir da proposta do senador liberal de São Paulo, José Bonifácio, o Moço, para a reforma da lei hipotecária de 24 de setembro de 1864, era claro o estrangulamento financeiro dos fazendeiros que haviam se submetido ao crédito hipotecário realizado pelo Banco do Brasil. Conforme assegurava Alfredo d'Escravagnolle Taunay, diretor da Sociedade Central de Imigração, em ofício enviado ao presidente do Banco do Brasil, o conselheiro José Machado Coelho de Castro, naquele momento o Banco do Brasil era

o verdadeiro senhor das melhores fazendas das provincias do Rio de Janeiro, Minas-Geraes, S. Paulo e Espirito-Santo, servidas por vias-ferreas, luxuosamente construidas com bitola mais larga do que as mais ricas estradas desse genero em França, Inglaterra e Estados-Unidos.

Os devedores insolvaveis são apenas prepostos tolerados pelo banco, na sua conhecida, e, ate certo ponto, obrigatoria condescendencia para com os grandes proprietarios.

Em algumas fazendas, senão em muitas, já desapparecerão até os donos, que as havião hypothecado, substituidos por gerentes que prestão contas diretas aos delegados do banco e pódem ser considerados simples feitores de numerosas turmas de escravos. ${ }^{44}$

O poder de ação política dos lavradores contrasta, e bastante, com a derrota deles pelo crédito real e agrícola. O primeiro ensaio, para isso, veio pela lei hipotecária de 24 de setembro de 1864, ampliada depois em 6 de novembro de 1875 e ratificada em 1879. Tal lei, para se fazer valer, necessitava da decretação do Banco de Crédito Real, cuja base era a importação de capitais estrangeiros com a garantia subsidiária do Estado, a qual seria concedida mediante um depósito no tesouro, em apólices, de vinte mil contos de réis, além da intervenção do governo na administração superior do estabelecimento. Os legisladores de 1875, como os de 1879, "declararam a impossibilidade de organizar-se sobre outras bases, nas condições atuais do país, o necessário crédito da lavoura reconhecendo a calamidade do alvitre de novas e fabulosas emissões de curso forçado com esse destino, assim como a falta de capitais nacionais que se empregassem a baixo juro na nossa lavoura" - escrevia em 1881 F. de P. Mayrink (p. 40).

Apesar de, em 1884, o Banco do Brasil ter parado de conceder hipotecas garantidas por escravos - um golpe mortal para os agricultores escravistas ligados à economia de exportação - um ano depois, no calor da discussão da reforma da

(44) “Banco do Brazil", Jornal do Commercio.Rio de Janeiro, 12 ago. 1885, p. 2. 
lei hipotecária de 1864, o Jornal do Commercio publicava a seguinte sugestão: "Corte o Banco do Brasil o nó gordium, liberte já todos os escravos que lhe estão hipotecados, e empreste aos fazendeiros as somas necessárias para as passagens de 50 colonos para cada fazenda. Os fazendeiros que estão desempenhados libertarão seus escravos, e estará abolida a escravidão no Brasil." 45 Ao que tudo indica, a Lei Hipotecária de 1885 deve ser lida à luz da aprovação da Lei dos Sexagenários e do desenvencilhar do Oeste paulista cafeicultor da tutela dos bancos da Corte.

Em suma, constata-se que, formada como força centrípeta, a economia urbana da Corte Imperial tornou-se uma espécie de esponja que absorvia e fazia drenar para si grande parte dos rendimentos brasileiros do período. E isso ocorria porque lá foram estabelecidos mecanismos capazes de ajustar a economia mercantil escravista cafeeira nacional ${ }^{46}$ à sua razão de ser, mecanismos de transferência do excedente produzido pela agricultura de exportação que permitissem: 1) que produzisse a economia exportadora cafeeira nacional, que se transformava em lucro ao se comercializar a sua produção no mercado urbano; 2) a criação de mercado de consumo corrente de produtos estrangeiros e nacionais e do escoamento de lá para as zonas interioranas de bens de consumo corrente estrangeiros; 3) que o lucro gerado na agricultura de exportação fosse apropriado quase integralmente pelos bancos e casas comerciais instaladas na Corte. ${ }^{47}$

\section{A política econômica de Conservadores e de Liberais}

A reforma financeira realizada por Itaboraí em 1853, então um dos cardeais do Partido Conservador, fez concentrar em um só banco, o Banco do Brasil instalado na capital do Império, o privilégio de emitir. Era política econômica do Partido Conservador realizar, através do monopólio por parte do Banco do Brasil, a concentração da emissão e enxugar o estoque monetário do país a fim de outros bancos não criarem crédito. Desse modo, se evitaria que as letras de prazo curto ou vales (de 5 dias, em regra) desses bancos viessem a circular como moeda, fazendo concorrência ao papel do Tesouro, e que o excesso de papel-moeda, conseqüentemente, depreciasse o câmbio. Em outras palavras, a política monetária do Partido Conservador era centralizar em um só banco a emissão do papel-moeda para restringir a circulação fiduciária e o crédito, a fim de

(45) Jornal do Commercio. Rio de Janeiro, 07 set. 1885, p. 4.

(46) Cardoso de Mello (1998), a economia nacional cafeeira escravagista caminhou inexoravelmente para a inviabilidade histórica.

(47) Conforme concluiu Sweigart, sobre a contínua expansão cafeeira ocorrida no Vale do Paraíba fluminense entre 1850 e 1881: "O fazendeiro certamente tinha suas obrigações financeiras, mas elas não impossibilitaram a acumulação de capital. Ao contrário, o acesso a dinheiro emprestado baseado na expectativa de renda proveniente de futuras vendas de café estimulou a acumulação. O vigoroso comércio de importação do século XIX e o crescimento dinâmico da cidade do Rio de Janeiro como um centro comercial, atestam a vitalidade da economia de exportação baseada no café.” Apud Slenes (1986, p. 109). 
manter uma moeda brasileira forte e estável, bem como o câmbio valorizado para facilitar o repagamento do considerado débito estrangeiro da nação.

Já a política monetária do Partido Liberal podia ser exemplificada através da emblemática atuação de Bernardo de Souza Franco, quando ele esteve à frente do Ministério da Fazenda de 4 de maio de 1857 a 12 de dezembro de 1858. Ao contrário dos cardeais do Partido Conservador, Souza Franco criou na sua gestão seis novos bancos emissores com sedes nas províncias do Rio Grande do Sul, Pernambuco, Bahia e Maranhão, em que a garantia do valor do meio circulante era sobre títulos do crédito público nacional. Assim, ao mesmo tempo em que a emissão plural e a distribuição de crédito patrocinada pelo Estado tendiam a desvalorizar o câmbio e acentuar a inflação, aumentando a dívida interna, elas também facilitavam os empreendimentos brasileiros, ao impulsionar o comércio, mesmo aquele que não estava ligado à exportação, as indústrias, os bancos domésticos (desde que tivessem poucas obrigações estrangeiras) e a agricultura de exportação.

Quanto à noção prevalecente de que a desvalorização do câmbio beneficiaria o setor de exportação e, portanto, a indústria cafeeira encorajava a desvalorização cambial, pois assim ela seria remunerada pelas moedas mais fortes das nações mais desenvolvidas, há de se notar que a produção cafeeira era formada pelos grupos - na maioria das vezes distintos - de agricultores, comissários e exportadores. Os agricultores eram favoráveis ao câmbio desvalorizado e até à emissão de moeda, mesmo que inflacionária, mas a possibilidade inflacionária e a desvalorização cambial assustavam os grupos comerciais mais representativos no setor de exportação de café. Em suas atitudes em relação à questão cambial, as associações comerciais demonstraram interesses opostos. Os grupos comerciais e agricultores do Nordeste eram favoráveis à desvalorização cambial, ao contrário das associações comerciais de Santos e do Rio de Janeiro - dominadas por estrangeiros e representantes de casas comerciais engajadas tanto na exportação quanto na importação - dos financiadores do exterior e dos investidores estrangeiros que pressionavam a favor da alta do câmbio (Ridings, 1994, p. 138144).

A inter-relação entre circulação monetária e câmbio, que fazia do excesso de papel inconvertível em ouro o maior causador das variações do câmbio entre a praça do Rio e a de Londres, era fato nos anos de 1866 a 1871. Mas isso ocorreu não porque o Banco do Brasil facilitou o crédito, pois foi justamente nesse período que o Banco do Brasil resgatou mais da metade de suas notas, conforme acordo de 1866 (que proibiu o banco de emitir notas e tornou-o mais independente do governo). Foi o governo quem aumentou o dinheiro em circulação em mais da 
metade, forçando a queda do câmbio em Londres em até 14 pence para cada milréis, em 1867, o mais baixo de todo o Império. ${ }^{48}$

A Guerra do Paraguai forçou o governo a se apropriar de todo o ouro do Banco do Brasil, ouro este que foi para o Prata, enriquecendo os fornecedores argentinos alocados principalmente em Buenos Aires, e para a Europa, com a compra de armamentos. ${ }^{49}$ Para financiar os gastos de guerra, tanto a administração conservadora quanto a liberal foi obrigada a aumentar a circulação de papéis fiduciários através do curso forçado. ${ }^{50}$

Normalmente, os estadistas do Império queixavam-se do excesso de papel-moeda e conseqüente depreciação do câmbio. Para o liberal Affonso Celso de Assis Figueiredo, no entanto, não havia nenhuma correlação entre meio circulante e taxa cambial. Em discurso de 18 de março de 1879, proferido na Câmara dos Deputados, o futuro Visconde de Ouro Preto dizia que a prova de que

(...) a nossa circulação fiduciaria não influe nesta praça para a quéda do cambio; fornecem-na tres factos altamente significativos.

Os annos de 1859 a 1860 marcam a epoca da maior expansão de credito entre nós. Foi então que a emissão do papel-moeda teve mais brusco e mais consideravel augmento.

Desapparecera a moeda metallica; emittia o thesouro, diversos bancos emittiam e tambem suas caixas filiaes.

Os 51 mil contos, que tinhamos em circulação, subiram rapidamente a 90 mil. Entretanto o cambio nunca desceu de 23 e subiu a $27 \mathrm{ds}$...

Quinze annos mais tarde, ${ }^{51}$ o cambio estava entre 25 e 26 ds.; deu-se nesta praça uma crise monetaria; os bancos sentiam-se ameaçados, e o governo entendeu dever ir em seu auxilio. Foi autorizada uma emissão de 25.000:000\$; e o que aconteceu?

O cambio, longe de baixar, subiu até 28 , e foi além, chegando a 28 3/8, á proporção que o papel ia-se introduzindo na circulação; e, ao contrario, quando o governo tratou de receber esta nova emissão, foi descendo até $24 !$. . .

(48) Ao relacionar o câmbio com as notas do Estado, as notas do banco e os bilhetes do Tesouro durante os anos de 1866 a 1871, Castro Carreira mostra que foram as notas do Estado que fizeram depreciar o câmbio. Cf. Carreira (1889, p. 441).

(49) Schulz (1996, p. 44-45). O Partido Liberal governou de 24 de maio de 1862 (17 Gabinete) a 16 de julho de 1868 ( $22^{\circ}$ Gabinete), e o Partido Conservador desta data até 5 de janeiro de 1878 (26ํㅡㅁ Gabinete).

(50) Entenda-se curso forçado como a declaração de que instrumentos como papel-moeda ou bilhetes bancários devem ser aceitos em pagamento pelo seu valor nominal, sem levar em conta o valor atual desses instrumentos em metal. Sobre os recursos extraordinários de que lançou mão o Tesouro Nacional para fazer face às despesas da guerra do Paraguai, ver Carreira (1889, p. 427). Para Granziera (1979), nesse período de guerra, o governo foi obrigado a realizar uma renovação do meio circulante através do curso forçado, abrindo vantagens inéditas ao comércio atacadista local, em cujo contexto iria se dar a verdadeira acumulação de capital.

(51) Refere-se à crise de 1875, que fizera os preços do café cair e obrigou Mauá a suspender as operações de seus bancos. Essa crise teve como causa externa o início da "grande depressão" mundial originada na Europa central, na Inglaterra e nos Estados Unidos a partir de maio de 1873. Cf. Schulz (1996, p. 33-48). 
Ainda agora mesmo, por occasião do decreto promulgado pelo meu illustre antecessor, $^{52}$ não houve nenhuma baixa de cambio. Pelo contrario, houve alta . . .

Logo o papel-moeda não influe para a baixa do cambio. ${ }^{53}$

Com exceção do período da Guerra do Paraguai (1864-1870), ao longo do Segundo Reinado é possível distinguir que eram diametralmente opostas as políticas monetárias de Liberais e de Conservadores, quando um deles estava no comando da pasta da Fazenda: enquanto aqueles tomavam medidas para descentralizar a emissão e aumentar a moeda em circulação para facilitar o crédito e estimular as transações comerciais internas e o setor exportador; esses procuravam segurar as rédeas da economia ao centralizar a emissão e enxugar o meio circulante para manter uma moeda brasileira forte e estável e uma taxa cambial alta.

Ao aumentar as moedas em circulação, o Partido Liberal conseqüentemente estimulava a especulação na bolsa de valores, o que desestabilizava o valor da moeda, mas aumentava os rendimentos dos exportadores. Mas, ao mesmo tempo, ele procurava reduzir os gastos públicos para assim poder reduzir os impostos. Já o Partido Conservador, mesmo aplicando medidas monetárias restritivas para estabilizar o valor da moeda e dar impulso a uma taxa cambial alta, também favorecia as grandes casas comerciais engajadas na importação, as instituições bancárias inglesas e aumentava os gastos públicos, o que o forçava a financiar a dívida pública através da alta de juros, do aumento de impostos e da realização de empréstimos externos.

De uma perspectiva política, seria provável, como já salientou Raymundo Faoro, ${ }^{54}$ que os fazendeiros estivessem mais próximos do Partido Liberal do que do Conservador, visto que os mandamentos descentralizadores e até federalistas dos liberais poderiam atribuir o comando político aos poderes locais, já que, do outro lado, o Partido Conservador, com seus próceres Vasconcelos, Olinda, Eusébio, Itaboraí, Uruguai e Paraná, apesar de ter estabelecido uma aliança de magistrados e fazendeiros, essa ligação estava sobreposta pelo princípio que fez

(52) Trata-se do decreto de 15 de abril de 1878, autorizando o Ministério da Fazenda a emitir, nos exercícios de 1877-78 e 1878-79, até a importância de 60.000:000\$ de papel-moeda para acudir às urgentes despesas da seca que devastava as províncias do Norte e às demais obrigações contraídas pelo Tesouro. Na volta ao poder do Partido Liberal, no 27o gabinete que teve começo em 5 de janeiro de 1878 e deixou o poder em 28 de março de 1880, no ministério presidido pelo conselheiro Sinimbú estava na pasta da Fazenda Gaspar da Silveira Martins, substituído interinamente por João Lins Vieira Cansanção de Sinimbú e em 8 de fevereiro de 1879 por Affonso Celso de Assis Figueiredo.

(53) Apud Cavalcanti (1890, p. 169). (O destaque está na edição citada.)

(54) Sigo as hipóteses de trabalho lançadas por Faoro (1988, p. 341-397). 
surgir o Partido Conservador: o fundamental e preponderante princípio do triunfo do centralismo. 55

Contra as tendências centrífugas desencadeadas durante a Regência (18311840), o Partido Conservador, diante do território já herdado, vislumbrou que, além do território, um Estado se define pela centralização do poder (político e administrativo). Estabelecido por sua elite política nacional, o Estado monárquico precisava - aliás, como qualquer Estado - de receita para se manter.

Os gabinetes conservadores e liberais, ao lidarem com as contas do governo agiam de forma diferenciada: o Partido Conservador mostrava, através do orçamento aprovado, estar mais próximo dos grupos comerciais mais representativos do setor exportador e importador e da concentração do poder no Rio de Janeiro através do monopólio de emissão; ao contrário do Partido Liberal, que com determinada linha orçamentária tendia a favorecer os empreendedores nacionais e os produtores rurais.

Mas, que fique claro, essas considerações não significam dizer que o Partido Liberal, quando no comando do centro decisório do poder, estava lá com o precípuo objetivo de governar em nome e para os senhores grandes proprietários rurais e para os empreendedores e comerciantes nacionais; e que, na outra margem, o Partido Conservador, quando no poder, seria o porta-voz e defenderia os interesses das grandes casas comerciais importadoras e exportadoras, dos banqueiros e dos senhores do crédito. ${ }^{56}$

Mesmo que as medidas de extinção do tráfico e as leis abolicionistas tenham saído todas de gabinetes conservadores, a crônica política diária dos debates e resoluções realizados na Câmara, Senado, Conselho de Estado, dissoluções da Câmara, na subida e descida dos partidos do comando dos Gabinetes, revela-nos que é um exagero caracterizar o quadro institucional, o

(55) Sobre os princípios do Partido Liberal, instaurados a partir de 1831, e os do Partido Conservador, datados de 1836 em diante, ver Brasiliense (1878). Uma investigação histórica da famosa afirmação atribuída a Hollanda Cavalcanti - "Não há nada mais parecido com um saquarema do que um luzia no poder" - ver Mattos (1987). Há de ressaltar que os dois partidos mantiveram uma fidelidade programática canina: o Partido Conservador defendeu sempre as instituições-base do Segundo Reinado: Poder Moderador, Senado vitalício, Conselho de Estado, através de ações políticas centralizadoras - enquanto o Liberal as combateu, inclusive através de rebeliões.

(56) Carvalho (1980, p. 165-166) afirma que conquanto houvesse diferenças de interesse na composição dos Partidos Liberal e Conservador, eram eles em comum formados por pessoas ligadas ao setor agrário: “(...) Os donos de terra que se ligavam ao Partido Conservador tendiam a pertencer a áreas de produção agrícola voltada para a exportação e de colonização mais antiga, como Pernambuco, Bahia e, principalmente, Rio de Janeiro. Estes grupos tinham mais interesses na política nacional e na estabilidade do sistema. Daí se disporem mais facilmente a apoiar medidas favoráveis ao fortalecimento do poder central. Os donos de terras filiados ao Partido Liberal provinham mais de áreas como Minas Gerais, São Paulo e Rio Grande do Sul, com menos interesses na centralização e na ordem ao nível nacional." 
Política, agricultura e a reconversão do capital do tráfico transatlântico de escravos para as finanças brasileiras...

Estado, como somente um instrumento da dominação ora dos senhores grandes proprietários rurais, ora dos senhores do grande comércio e dos financiadores. ${ }^{57}$

\section{Conclusão}

Com a abolição do comércio negreiro internacional, o capital da cáfila de negreiros foi absorvido pelo mecanismo bancário e monetário monitorado pelo Partido Conservador. A inversão do capital dos mercadores negreiros para a capital do Império foi o fator preponderante que catalisou o maior centro financeiro e comercial do país, configurando nela uma economia urbana mercantil cuja dinâmica entrelaçou o veio exportador agrícola com o veio importador de manufaturados e alimentos.

Num lance político realizado pelo Partido Conservador, a exígua economia monetária brasileira foi garroteada por um mecanismo centralizador que fazia com que todos os rendimentos monetizados fossem remetidos para a Corte. Os comerciantes dessa cidade, aliados à tradição mercantilista, financiaram e ganharam com a importação dos mais diversos produtos, fazendo do Rio um centro importador e consumista.

Dessa forma, as amarras do sistema bancário ao desenvolvimento econômico não foram somente uma conseqüência lógica da dinâmica do capital mercantil, mas foram também o resultado do mecanismo político construído pelo Partido Conservador. A política monetária e fiscal implementada pelos conservadores fez com que todo o ritmo de acumulação dependesse das institucionalizações estatais, subordinando a agricultura exportadora, atravancando o desenvolvimento manufatureiro e drenando os lucros monetizados da acumulação produtiva mais dinâmica do país para a capital do Império. A Corte, constituindo-se no epicentro da economia nacional, vai absorver os lucros produtivos através do sistema bancário e de crédito, que, por sua vez, realimentava, através dos comissários, a produção agrícola exportadora e tonificava a importação de bens de consumo.

\section{Fontes Primárias Impressas}

\section{Relatórios, Livros, Teses e Artigos}

LEAL, Antonio Henriques. Locubrações. Lisboa: Typographia Castro Irmão, 1874.

(57) No livro, Carvalho (1980) mostrou que a elite política freqüentemente provou ser capaz de agir contra poderosos setores da classe dominante. Um forte exemplo disso foi a promulgação da Lei do Ventre Livre, pelo Gabinete conservador chefiado pelo Visconde de Rio Branco, que foi realizada apesar da ferrenha oposição dos plantadores de café das três províncias-chave do Império: Rio, São Paulo e Minas. Para um acompanhamento, a partir de informações colhidas de um dos protagonistas da época, dos bastidores e negociações que envolveram a aprovação da Lei do Ventre Livre, ver Barreto (1913, p. 11-34).

Economia e Sociedade, Campinas, v. 17, n. 3 (34), p. 463-491, dez. 2008. 
Artur Vitorino

MAYRINK, Francisco de Paula. O cambio-a producção-o governo: artigos publicados na imprensa da Corte em maio de 1881. Rio de Janeiro, Typographia do Cruzeiro, 1881.

SOARES, Sebastião Ferreira. Elementos de estatistica comprehendendo a theoria da sciencia e a sua applicação á estatistica commercial do Brasil. Rio de Janeiro, Typographia Nacional, Tomos I e II, 1865.

Notas estatisticas sobre a producção agricola e carestia dos generos alimenticios no Imperio do Brazil. Rio de Janeiro, Typ. Imp. e Const. de J. Villeneuve e Comp. 1860.

SOUZA, Irineu Evangelista de. Visconde de Mauá. Autobiografia, exposição aos credores e ao público, seguida de $O$ meio circulante no Brasil. Rio de Janeiro, Zélio Valverde, 1948.

\section{Jornais}

Correio Mercantil, Rio de Janeiro.

Jornal do Commercio, Rio de Janeiro.

\section{Revistas e Almanaques}

Bibliotheca Brasileira. Revista mensal por uma associação de homens de letras, Rio de Janeiro.

Revista da Associação dos Guarda-Livros, Rio de Janeiro.

\section{Bibliografia: Livros e artigos}

ALENCASTRO, Luiz Felipe de. Le Commerce des vivants: Traite d'Esclaves et "Pax Lusitana” dans L'Atlantique Sud, thèse de Doctorat de l'Université de Paris X, 1985-1986, mimeo.

Bahia, Rio de Janeiro et le nouvel ordre colonial 1808-1860. In CHASE, Jeanne (org.). Géographie du capital marchant aux Amériques 1760-1860. Paris, École des Hautes Etudes, 1987, p. 131-147.

- Vida Privada e Ordem Privada no Império, in: História da vida privada no Brasil: Império. São Paulo: Companhia das Letras, 1997.

. O trato dos viventes: formação do Brasil no Atlântico Sul. São Paulo: Companhia das Letras, 2000.

BUESCU, Mircea. História econômica. Pesquisas e análises. Rio de Janeiro, APEC, 1970.

FAORO, Raymundo. Os donos do poder: formação do patronato político brasileiro. Rio de Janeiro, Globo, 8. ed., 1988.

FARIA, Alberto de. Mauá. Irenêo Evangelista de Souza, Barão e Visconde de Mauá, 1813-1889. Rio de Janeiro, Paulo: Pongetti \& Cia, 1926.

FERREIRA, Marieta de Moraes. A crise dos comissários de café do Rio de Janeiro. Niterói, UFF, Dissertação de Mestrado, 1977. Mimeografado. 
Política, agricultura e a reconversão do capital do tráfico transatlântico de escravos para as finanças brasileiras...

GRANZIERA, Rui Guilherme. A guerra do Paraguai e o capitalismo no Brasil: moeda e vida urbana na economia brasileira. São Paulo: HUCITEC; Campinas: UNICAMP, 1979.

LEVY, Maria Bárbara. A indústria do Rio de Janeiro através de suas sociedade anônimas. Rio de Janeiro: Editora UFRJ; Secretaria Municipal de Cultura do Rio de Janeiro, 1994.

; ANDRADE, Ana Maria Ribeiro de. Fundamentos do Sistema Bancário no Brasil: 1834-1860. Estudos Econômicos, 15 (Número Especial) 17, p. 48, 1985.

LÔBO, Eulália Maria Lahmeyer. História do Rio de Janeiro (do capital comercial ao capital industrial e financeiro). 2 vol. Rio de Janeiro, IBMEC, 1978.

MELLO, Evaldo Cabral de. O Norte agrário e o Império, 1871-1889. $2^{\mathrm{a}}$ ed. revista. Rio de Janeiro, Topbooks, 1999.

MELLO, João Manuel Cardoso de. O capitalismo tardio. Contribuição à revisão crítica da formação e do desenvolvimento da economia brasileira. $10^{\mathrm{a}}$ ed., Unicamp/IE, Campinas, 1998.

NORMANO, J. F. Evolução economica do Brasil. São Paulo, Companhia Editora Nacional, 1939.

SLENES, Robert W. The demography and economics of Brazilian slavery: 1850-1888. Stanford, Stanford University, 1976.

Grandeza ou decadência? O mercado de escravos e a economia cafeeira da província do Rio de Janeiro, 1850-1888. In: COSTA, Iraci del Nero da (Org.). Brasil: história econômica e demográfica. São Paulo, IPE/USP, 1986, p. 103-151.

STEIN, Stanley J. Grandeza e decadência do café no Vale do Paraíba: com referência especial ao município de Vassouras. São Paulo, Brasiliense, 1961.

SWEIGART, Joseph E. Financing and marketing Brazilian export agriculture: the coffee factors of Rio de Janeiro, 1850-1888, tese de Ph.D, University of Texas at Austin, 1980. 